
Publications of thf Bureau of Business and Economic Research UNIVERSITY OF CALIFORNIA

\author{
Some recent publications in this series: \\ MONETARY POLICIES AND FULL EMPLOYMENT \\ by William Fellner $(1946,1947)$ \\ TAXING MUNICIPAL BOND INCOME \\ by Lyle C. Fitch (1950)
}

CRISIS IN BRITAIN: PLANS AND ACHIEVEMENTS OF THE LABOUR GOVERNMENT by Robert A. Brady (1950)

SCIENTIFIC METHOD FOR AUDITING

by Lawrence L. Vance (1950)

APPLICATION OF LINEAR PROGRAMMING TO THE THEORY OF THE FIRM

by Robert Dorfman (1951)

COMPREHENSIVE CLASSIFIED MARKETING BIBLIOGRAPHY, PARTS I AND 2

by David A. Revzan (1951)

UNCLE SAM IN THE PACIFIC NORTHWEST

by Charles McKinley (1952) 


\section{THE AGE STRUCTURE OF THE CORPORATE SYSTEM}





\section{Publications of the \\ Bureau of Business and Economic Research \\ University of California}

\section{THE AGE STRUCTURE OF THE CORPORATE SYSTEM}

BY

WILLIAM LEONARD CRUM

UNIVERSITY OF CALIFORNIA PRESS

BERKELEY AND LOS ANGELES

1953 


\section{UNIVERSITY OF CALIFORNIA PRESS}

BERKELEY AND LOS ANGELES

CALIFORNIA

$\infty$

CAMBRIDGE UNIVERSITY PRESS

LONDON, ENGLAND *

COPYRIGHT, 1953, BY

THE REGENTS OF THE UNIVERSITY OF CALIFORN1A

PRINTED IN TME UNITED STATES OF AMERICA

BY THE UNIVERSITY OF CALIFORNIA PRINTING DEPARTMENT 


\title{
BUREAU OF BUSINESS AND ECONOMIC RESEARCH
}

\author{
NORMAN S. BUCHANAN, CHAIRMAN \\ GEORGE F. BREAK \\ JOHN P. CARTER \\ EWALD T. GRETHER \\ MELVIN M. KNIGHT \\ MAURICE MOONITZ \\ PAUL S. TAYLOR
}

FRANK L. KIDNER, DIRECTOR

The opinions expressed in this study are those of the author. The functions of the Bureau of Business and Economic Research are confined to facilitating the prosecution of independent scholarly research by members of the faculty. 

To

Dr. Thomas C. Atkeson of the Bureau of Internal Revenue, United States Treasury, who has, during many years, contributed greatly to enlarging the scope and refining the quality of Statistics of Income, this book is respectfully dedicated. 
